\title{
Češi jsou Evropany
}

\author{
Alexandr Ort $^{1}$
}

Členství Česka v Evropské unii je realitou a zbývá tedy jen otázka, zda jsou Češi už dnes Evropany nebo si na to budou teprve muset zvykat a nebo se to dokonce učit.

Evropská integrace je sice výtvorem teprve druhé poloviny dvacátého století, ale v 21. století už je Evropská unie dominantní a integrující silou celé evropské politiky a dokonce s výhledem výrazně jménem Evropy ovlivňovat i politiku světovou.

České země byly vždy nejrůznějším způsobem součástí Evropy, a proto i jejich obyvatelé patřili do Evropy. Dokud byla Evropa feudální, byly státy více či méně útvary vládnoucích rodů. České dějiny o tom svědčí velmi výrazně, at̃ už šlo o Přemyslovce nebo poté Lucemburky a koneckonců i Habsburky. Jistě to bylo vždy rozdílné, ale obyvatelstvo to nemohlo nijak významněji ovlivnit, s výjimkou husitství.

O českém národu můžeme hovořit až do devatenáctého století, kdy pod vlivem demokratických idejí Francouzské revoluce 1789, „Volnost, rovnost, bratrstvi“, se moderní národy počaly ustavovat a uvědomovat. Zvlášt výrazně se to projevilo ve střední Evropě, kde také odedávna Češi sídlili.

A právě národní uvědomování probíhalo u českého národa do velké míry odlišně od ostatních. Souviselo to se skutečností, že po třicetileté válce došlo k masovému odchodu české většinové kališnické šlechty, podřízení katolické šlechty vídeňskému dvoru a příchodu cizích šlechtických rodů díky konfiskaci majetků emigrantů císařem a jejich přidělení různým kondotierům z války, o něž se císařské vojsko opíralo.

Díky tomu všemu se ve městech, jejichž význam rostl, čeština stala jazykem téměř výhradně řemeslníků a nižších středních vrstev a masově se udržela jen na venkově. Šlechta hovořila různými jazyky a její spojení se zemí souviselo pouze s její rozsáhlými majetky, a její vztah k císaři byl určován jen jeho respektováním jejích stavovských práv.

V německém jazyce se vytvořila zvláštní situace, že pro výraz „český“ má dva výrazy: „tschechisch“ a „böhmisch“. Rozdílnost spočívala v tom, že druhý výraz se týkal především země, a většina šlechty se proto hlásila k böhmisch, zatímco tschechisch označoval to, co se týkalo obrozujícího se českého národa. A snad i to přispívalo k tomu, že císařský dvưr nebyl nikdy schopen pochopit potřeby českého národa.

Český národ prožíval svou obrodu v devatenáctém století odlišně od ostatních národů střední Evropy, a to se nemohlo neprojevit v jeho mentalitě. Zatímco Němci, Poláci, ale i Mad'ařnebo Rusové se ve svém kulturním a jazykovém vývoji mohli opírat o šlechtu, česká zemská šlechta zůstávala, až na poměrně nepočetné výjimky, k problematice národního obrození lhostejná. A tak se český národ v obrozovacím procesu musel opírat především o postupně se vytvářející českou inteligenci.

Do středních a vysokých škol se čeští mladíci dostávali dosti těžko, nejvýš jen z bohatších rodin řemeslníků, malých obchodníků a sedláků a později i z rodin českých intelek-

1 Prof. Dr. Alexandr Ort, DrSc., Středisko mezinárodních studií J. Masaryka Fakulty mezinárodních vztahů Vysoké školy ekonomické v Praze. 
tuálů. Navštěvovat museli školy německé, naplněné duchem klerikalismu a podřízené vídeňským vládám. Tam převratné myšlenky francouzské revoluce pronikaly jen velmi obtížně a většinou se o nich nesmělo ani mluvit. Ale zakázané ovoce chutná mládeži nejvíce a demokracie se stávala idejí nejen studentů, ale i jejich rodin, což se zákonitě promítalo i do institucí samosprávy, která se v Evropě začala výrazněji prosazovat.

Složitost hledání politického programu pro rodící se české národní hnutí spočívala v tom, že české země nebyly národnostně jednotné, ale vedle české většiny zde pưsobila i německá menšina, opírající se o germanizační politiku císařského dvora. Ale i pro Němce $\mathrm{v}$ českých zemích nebylo vždy snadné najít správné politické zaměření, nebợ zde byli rakouští Němci s vedoucím postavením v habsburské řiši, avšak nuceni přece jen brát jisté ohledy na neněmecké národy. Navíc v bezprostředním sousedství českého a moravského pohraničí se právě v devatenáctém století výrazně v evropské politice prosazoval Německý spolek pod vedením Pruska a později pak sjednocené Německo a zde se nabízelo pro ně větší národní uspokojení.

V evropské politice se od napoleonských válek stále výrazněji uplatňoval mocenský zájem carského Ruska, proti němuž se vytvářelo jakési společenství Pruska a Rakouska, i když plné různých protikladů a rozporů. Zároveň však v rámci „Svaté aliance“ všechny tyto tři státy usilovaly o udržení starých pořádků a zastavení růstu revolučních myšlenek.

Revoluce v Evropě v roce 1848 byla odrazem zásadně se měnící situace na kontinentě. Češi dopisem Palackého do Frankfurtu odmítli se podílet na sjednocovacím procesu v Německu, který by znamenal zánik českého národa. Česká politická reprezentace hledala cesty k zachování mnohonárodnostního rakouského státu jako prostoru, kde by se český národ, a podobně i další neněmecké národy, mohly rozvíjet. V době velkých řî́śí na mapě Evropy a sjednocovacích tendencí Italů a Němců nebyla pro Čechy nejmenší šance pomýšlet na samostatný stát.

A tak modernizované, tedy demokratizované a národnostně federované Rakousko se mohlo stát vhodným prostorem pro rozvoj českého národa. Proto také čeští poslanci na říšském sněmu v Kroměříži předložili v roce 1849 velmi promyšlené a moderní návrhy zákonů, které jediné mohly dát středověkému státnímu útvaru, jakým bylo Rakousko, nové uspořádání odpovídající potřebám devatenáctého století. Nestalo se tak, a tak návrat k absolutismu císaře po překonání revoluční vlny bylo startem $\mathrm{k}$ zániku habsburské řǐše.

Politika českého národního obrození se řídila zásadou, formulovanou v známém Palackého výroku, že „kdyby státu rakouského nebylo již odedávna, museli bychom v interesu Evropy, ba humanity přičinit se co nejvíce, aby se utvořil“. Dostala název ,austroslavismus", ale z Palackého slov vyplývá, že si plně uvědomoval př́ílušnost Čechů k Evropě a že měl na mysli i ještě daleko obecnější aspekty politiky celého lidstva.

Novou dimenzi dostala situace v Rakousku, když po porážce od Pruska v roce 1866 došlo k rakousko-uherskému vyrovnání, ale navíc i k růstu závislosti Rakousko-Uherska na Německém císařství v evropské politice. Tehdy opět Palacký prorocky viděl neblahou budoucnost habsburské ŕíše, když před dualismem varoval a prohlásil: „Byli jsme před Rakouskem, budeme i po něm“.

Právě s pohledem na evropskou politiku se česká politická reprezentace pokusila kontaktovat ruského cara, ale ten dal dynastickému př́stupu přednost před eventuálními mocenskými zájmy Ruska, mimo jiné asi se vždy obával rebelů a revolucionářủ a Čechy zřejmě mezi ně počítal. Nepodařilo se jim také získat francouzského císaře Napoleona III., jemuž nedostatek představivosti nedovolil pochopit význam spojenectví s Čechy pro Francii. 
České národní hnutí si dobře uvědomovala propojenost evropské politiky, ale její nepochopení vládci jiných mocností nedalo Čechům šanci hledat za dané situace jiné cesty pro národní rozvoj než v rámci Rakousko-Uherska.

Hospodářský rozmach českých krajů a měst, spojený s růstem národního uvědomění širokých vrstev obyvatelstva, vedoucí $\mathrm{k}$ většímu zastoupení Čechů ve volených samosprávních orgánech, především radnic $\mathrm{v}$ městech, znamenal růst vlivu českých zemích $\mathrm{v}$ rámci habsburské říše. Silně demokratický aspekt českého národního hnutí ztěžoval jeho spolupráci s českou zemskou šlechtou, která byla ochotna podporovat jen ty české požadavky, adresované císaři, jež se nějak týkaly jejích majetků. Vliv české zemské šlechty navíc postupně značně slábl v důsledku industrializace státu a s tím spojeného poklesu role zemědělství v národním hospodářství a také významu pozemkového majetku vůbec.

Vztah českého národního hnutí $\mathrm{k}$ české šlechtě oslaboval i jeho důsledně demokratický přistup k řešení všech politických otázek doby. Rozmach spolkového života, založeného na rovnosti všech členů a vzájemném tykání, jehož nejvýraznějším př́íkladem byl rychle početně rostoucí a společensky se rozvíjející vliv „Sokola“, nebyl př́liš po chuti šlechtě ani české, ani rakouské. Navíc převzetí červených košil italských revolucionářů vedených G. Garibaldim do sokolského stejnokroje rozhodně nebylo pro tyto kruhy doporučením.

Boj české politické reprezentace o splnění oprávněných požadavků českého národního hnutí, směřující k jakémusi trialismu habsburské řîše, byl po vzniku Rakousko-Uherska mimořádně obtižný, nebot narážel na odpor nejen Němců, ale i Uhrů, žárlivě střežících dualismus. Císařský dvůr a některé ze stř́dajících se vlád ve Vídni si byly vědomy nutnosti respektovat některé oprávněné požadavky hospodářsky nejvyspělejší části habsburského mocnářství, ale i sebemenší ústupky, jako byly „fundamentálky“ v roce 1871 nebo „punktace" o dvacet let později, ztroskotaly na společném odporu německých a uherských zástupců.

Rychlý růst gramotnosti širokých vrstev českého obyvatelstva se mimo jiné mohl opírat o výborné překlady vrcholných děl světové literatury, jimž se věnovali nejlepší spisovatelé vedle své vlastní tvorby. To významně přispívalo $\mathrm{k}$ širšímu pohledu na okolní svět díky znalostem anglické, francouzské, italské, německé a ruské soudobé literatury, ale i největších děl latinské a řecké antiky. K širšímu pohledu na evropské reálie přispívalo mimo jiné i to, že česká veřejnost s velkým zájmem sledovala vše, co se dělo v evropské politice zvláště na Balkánském poloostrově a sympatizovala s bojem slovanských národů proti turecké nadvládě.

S tím spojené úvahy o významu slovanstva pro budoucnost Evropy, o němž se často psalo i v německých novinách, i když většinou v negativním pojetí, posilovaly víru v lepší budoucnost i pro český národ. A nešlo jen o Rusko, slovanské národy žily i v Rakousko-Uhersku a s nimi bylo možno spolupracovat. Mnoho pro to udělal T. G. Masaryk jako poslanec, když se např́íklad zastal Chorvatů v různých velezrádných procesech v Záhřebu nebo později se pokusil prostředkovat mezi Srbskem a vídeňskou vládou v předvečer světové války.

Snaha Rakousko-Uherska hrát i nadále úlohu velmoci v evropské politice dávala české veřejnosti informace o jeho zahraniční politice a Češi s velkým potěšením zaznamenávali všechny neúspěchy rakousko-uherské diplomacie, ke kterým docházelo. Ale to právě zvyšovalo zájem české veřejnosti o vše, co se v Evropě událo a co mohlo český boj o národní rozvoj posílit.

Demokratický, a trochu i populistický charakter české společnosti byl ještě posílen, když se vytvořily první dělnické organizace. Na rozdíl od mnoha evropských států se v českých zemích nedostaly do úplné politické izolace, ale jisté kontakty s ostatními politickými 
stranami i přes různé rozpory existovaly. A to opět přineslo do české politiky prvek jisté národnostní tolerance, nebot dělnické organizace vznikaly na jiné než národní základně a usilovaly o společný boj bez ohledu na státní hranice. I proto si česká veřejnost zachovala zvýšený zájem o vše mezinárodní a dovedla chápat potřebu širších vazeb ve svém úsilí o svobodný rozvoj.

Česká politická reprezentace se na přelomu devatenáctého a dvacátého století značně diferencovala do různých politických stran, ale až na malé výjimky zůstávala věrna v boji za rozvoj českého národa úsilí o modernizaci Rakousko-Uherska v duchu Palackého. Prosazení všeobecného volebního práva pod vlivem revoluce v Rusku v roce 1905 znamenalo novou naději, že touto cestou by bylo možno prosadit některá demokratizační opatření.

Zásadní změnu přinesla až světová válka. Češi jednoznačně pochopili, že válka Rakousko-Uherska proti Srbům není jejich válkou, a také dobře vnímali, že vzrůstající podřízenost habsburské řríše zahraničně politickému zaměření císařského Německa přináší zhoršení podmínek pro rozvoj českého národa v rámci Rakousko-Uherska.

První období války a zvláště úspěchy ruských vojsk přinesly velkou, i když zcela neoprávněnou naději české veřejnosti na pomoc osvobození českých zemí z této strany. V orientaci na Rusko byl nejdůslednější K. Kramář, vedoucí představitel mladočechů, ale brzy se ukázala neoprávněnost těchto nadějí. Rusko, často označované za „obra na hliněných nohách“, prohrávalo na frontě s Německem a muselo se stáhnout i na úseku bojů s Rakousko-Uherskem.

Jinou orientaci si zvolila skupina kolem T. G. Masaryka, nazvaná opět podle italského vzoru „Mafií“. Z analýzy mezinárodní situace a z vyhodnocení poměru sil bojujících zemí včetně přesvědčení, že na straně Dohody vstoupí do války i USA, vyvodili závěr organizovat cílevědomý odboj v zahraničí ve spolupráci s dohodovými velmocemi. V první etapě války to byl krok značně odvážný, ale znovu odrážel širší přístup části politické reprezentace k pojetí své činnosti na základě celoevropského pohledu.

Navíc to vyžadovalo sebekritické přehodnocení dosavadních stanovisek v rámci tzv. austroslavismu, ale to bylo možno pochopit jen v případě, že si uvědomíme dlouhodobou spjatost českých mezinárodně politických úvah se širší analýzou celoevropské situace. A ta se válkou, která se postupně stávala světovou, skutečně zásadně měnila a tyto změny politického postoje si vynutila.

I když většina českých poslanců zůstávala věrna habsburskému domu, veřejnost sympatizovala se zahraničním odbojem, což dokazoval především postoj českých vojáků na frontách, dávajících se zajmout či přebíhajících, aby nemuseli bojovat proti slovanským bratřím, Rusům nebo Srbům. Také Češi v zahraničí byli ochotni se zapojit do boje v dohodových armádách a především v tvořících se samostatných československých jednotkách.

To byl nový prvek v politické orientaci českého zahraničního odboje, že od počátku usiloval o osvobození nejen Čechů, ale i Slováků. Proto také vedení odboje „Národní rada českých zemí“ se brzy stala „Československou národní radou“, v jejímž čele dva Čechy, T. G. Masaryka a E. Beneše doplnil Slovák M. R. Štefánik.

Všichni tř̌i byli na své úkoly velmi dobře připraveni. Masaryk už koncem devatenáctého století publikoval soubor článků o poměrech v zemi, z nichž jeden nesl přímo název „Česká otázka“. Autor ji označil za otázku světovou, opíral se přitom o českou historii a zdůrazňoval její humanitní a demokratický aspekt, odpovídající nastupujícím trendům v evropské politice. Byl to problém malého národa, usilujícího o kulturní a politickou emancipaci založenou na osvětové práci a povznesení vzdělanosti. E. Beneš, aby poznal Evropu, studoval progra- 
mově na univerzitách v Pařízii, Dijonu, Londýně a Berlíně a M. R. Štefánik pracoval delší dobu jako astronom ve Francii a dokonce získal její občanství.

Československý aspekt zahraničního odboje se ukázal velmi správným, nebở zprávy z front ukazovaly, že vedle Čechů se nejméně spolehlivými vojáky stávali Slováci, odmítající bojovat za Rakousko-Uhersko. V jistém směru to bylo dosti překvapivé, že národní uvědomění prostých vojáků mohlo sehrát tak velkou roli $\mathrm{v}$ jejich postoji $\mathrm{k}$ válce, a ještě překvapivější byla jejich orientace správným směrem, pokud šlo o vývoj válečných střetnutí. Potvrzovalo to také jejich schopnost vidět věci v mezinárodně daleko širším měřítku, než by se dalo předpokládat.

Správnost politické analýzy mezinárodní situace z hlediska vedení války československým zahraničním odbojem se poměrně brzy potvrdila, když jeho představitelé nacházeli značné pochopení u vlád dohodových velmocí. Nebylo to vždy jednoduché, ale nakonec širší, možno říci celoevropské hledisko u nich převládlo a uvědomili si, že Češi a Slováci, stejně jako Jihoslované mohou hrát nejen za války, ale i po válce ve vlastních státech, důležitou úlohu v evropské politice. A proto se jim dostalo od dohodových vlád podpory jak politické, tak materiální.

Ocenit je třeba při tom, že se v programových dokumentech podařilo spojit argumentaci v české otázce, orientovanou na historickou oprávněnost státní nezávislosti, s problematikou Slovenska, opřenou moderně o právo národů na sebeurčení. To souviselo s uznáním historických hranic Království českého a Markrabství moravského s vytýčením nových hranic slovenské části na severu Karpatským hřebenem jako starých hranic Uherského království a na jihu přirozenou hranicí na řekách Dunaji, Ipelu a Uhu.

Vytvoření legií jako vlastní československé armády bylo mimořádně významné nejen z hlediska vojensko-politického, ale stalo se i výrazným dokladem smýšlení prostých Čechů a Slováků, kteří se do nich dobrovolně zapojovali, nebot’ obyvatelstvo doma mohlo své názory vyslovovat jen velmi omezeně. O jeho smýšlení svědčilo jen pronásledování a tresty některých politiků či vojáků na frontách i v zázemí.

Širší než jen úzce národní pohled na poválečné uspořádání stř̌ední Evropy po rozpadu Rakousko-Uherska si Masaryk dokázal nejen představit, ale za svého pobytu v USA pro ně dokázal získat tamní emigrantské představitele většiny stř̌edoevropských národů. „Středoevropská demokratická unie“ se měla stát širším rámcem jejich spolupráce, až získají svobodu a nezávislost ve vlastních národních státech. Tuto ideu předložila jejich společná delegace pod Masarykovým vedením před koncem války i americkému prezidentu Wilsonovi.

Po otřesech, vyvolaných revolucemi v Rusku a po vyhlášení Wilsonových 14 bodů v Poselství Kongresu USA, začal nový rakousko-uherský císař Karel I. hledat cesty k záchraně habsburské říše, ale bylo už pozdě. Československá národní rada už byla uznána dohodovými mocnostmi de facto a Čechoslováci byli považováni za národ „spojenecký a válku vedoucí“.

Po amnestii nového císaře pro některé politické vězně se jen pomalu obnovoval politický život v českých zemích. Poslanci nejprve zaujali smiŕlivý postoj k nové císařské politice, ale skutečné názory veřejnosti se svět dozvěděl až na jaře 1918 z „Prohlášení českých spisovatelü“ oceňujícího, že „vývoj směřuje k Evropě demokratické, k Evropě národů svéprávných a svobodomyslných". A teprve potom i poslanci vyslovili svou podporu zahraničnímu odboji usilujícímu o samostatné Československo. 
Na podzim 1918 se ustavila československá prozatímní vláda v čele s T. G. Masarykem a byla hned uznána hlavními dohodovými mocnostmi. Základy uspořádání nového státu, jenž se měl stát republikou, obsahovalo „Prohlášení nezávislosti“ zveřejněné Masarykem 18. 10. 1918 ve Washingtonu a bylo nejdemokratičtějším dokumentem tohoto druhu na konci první světové války. V Československu mělo platit všeobecné a rovné volební právo, ženy měly být politicky, sociálně a kulturně rovny mužům, úplná měla být svoboda tisková, shromaždovací petiční a menšiny měly užívat stejných práv. Šlo jasně o demokratický stát, respektující lidská práva na úrovni nejvyspělejších zemí Evropy.

Česká veřejnost zcela jednoznačně a spontánně uvítala vznik nezávislého státu a plně se s ním ztotožnila. Manifestace 28. 10.1918 na Václavském náměstí, stejně jako prohlášení Slovenské národní rady v Turčianskom sv. Martine toho byly nejlepším dokladem. Prvním prezidentem se jednomyslně stal T. G. Masaryk a myšlenky Prohlášení nezávislosti, tzv. Washingtonské deklarace, se staly základem nové ústavy republiky, založené na demokratických zásadách, z nichž se česká společnost vždy snažila vycházet.

V nové vládě bylo početné německé menšině vyděleno jedno křeslo, ale Němci ho odmítli obsadit. Naopak se pokusili vznik Československa různým způsobem zdiskreditovat. Ale jejich protesty nebyly vítěznými velmocemi přijaty. Nový stát dokázal během osmi let vytvořit takové politické podmínky, že němečtí zástupci vstoupili do vlády a politika vůči národnostním menšinám v Československu byla Společností národů, která na její dodržování měla dohlížet, označována za velmi dobrou. Vedle Němců se to týkalo i většího počtu Mad’arů na jižním Slovensku a Poláků na severní Moravě.

Evropská dimenze se promítla i do koncepce československé zahraniční politiky, jež se aktivně zapojila do budování Společnosti národů v přesvědčení, že evropská bezpečnost by byla nejlepší zárukou bezpečnosti republiky. Místo Středoevropské demokratické unie, znemožněné nacionalismem některých nových států ve střední Evropě, se uskutečnilo jen jakési její torzo, jemuž se dostalo označení „Malá dohoda“. Československo, Jugoslávie a Rumunsko ji vytvořily na obhájení nových hranic stanovených mírovými smlouvami, a teprve později bylo možno hledat cesty k prohloubení spolupráce tří států a její rozšíření v jakési nadnárodní mezinárodní jednotce.

Československo bylo od samého počátku své existence považováno za důležitou část evropské politiky, a to zdaleka ne jen v důsledku jeho mírové zahraniční politiky, ale i proto, že jako konsolidovaný stát se ve středu Evropy stalo azylem pro demokraty a z národnostních důvodů pronásledované obyvatele ostatních států. Vedoucí jeho političtí představitelé, opírající se o zkušenosti z minulosti, dokázali problémy chápat šîreji než jen národně a byli považováni za osobnosti svou tolerancí přispívající významně ke stabilizaci stř̌ední Evropy.

V rámci Společnosti národů si Československo zajistilo úctu a sympatie všech, jimž ležela na srdci otázka míru a bezpečnosti v Evropě. Od samého počátku svého pưsobení v této mezinárodní organizaci hledali českoslovenští představitelé nejvhodnější formy smluvních záruk v tomto směru. A ne náhodou se československý ministr zahraničí stal v polovině dvacátých let zpravodajem výboru, který, když se do něj zapojily Francie a Velká Británie, připravil návrh „Protokolu o pokojném řešení sporů“, který Shromáždění Společnosti národů jednomyslně přijalo. Opíral se o tři sloupy, arbitráž, bezpečnost a odzbrojení, což ve své podstatě platí pro mírovou politiku stále. Odmítnutím ratifikovat protokol vzala na sebe nová britská vláda odpovědnost za to, že protokol se nikdy nestal součástí mezinárodního práva. 
Z britské iniciativy vytvořená „politika Locarna“ nemohla dlouhodobý záměr ženevského protokolu nahradit, nebot’ se týkala jen západní Evropy a neopírala se o spolupráci všech evropských států. Př́iliš se v ní odrážela britská snaha rozehrávat evropské mocnosti jednu proti druhé a pro sebe si zajistit postavení rozhodčího.

Světová hospodářská krize dolehla na Československo stejně drtivě jako na jiné evropské státy, ale východisko nehledalo ve fašismu nebo diktátorském režimu. Zůstalo věrno svému demokratickému zrrízení a naopak poskytovalo pomoc uprchlíkům ze států, které se vydaly cestou diktátu, především obyvatelům Německa, Polska a Rakouska.

Nástup fašismu v Evropě znamenal pro Československo bezprostřední ohrožení, neboł především německý nacismus se netajil svou nenávistí vůči demokratickému sousedu. V duchu své dlouhodobé koncepce boje za evropskou bezpečnost zapojilo se Československo do hledání cest k zajištění míru politikou kolektivní bezpečnosti.

V jejím čele stanula Francie, bezprostředně ohrožena veřejně vyhlášenou nenávistí nacistického Německa, a Sovětský svaz, který se v polovině třicátých let zapojil do evropské politiky vstupem do Společnosti národů. Československo se do tohoto procesu aktivně zapojilo právě v duchu svého evropského pojetí bezpečnosti a dohoda o letecké lince Paříž - Praha - Moskva se toho stala jakýmsi symbolem. Spojenecké smlouvy Francie s SSSR a ČSR s SSSR, doplňující už dřívější československo-francouzské spojenectví, se staly torzem pưvodně zamýšleného systému smluv o kolektivní bezpečnosti.

Československo zůstávalo jediným demokratickým státem ve stř̌edu Evropy, ale právě v roce 1935 muselo čelit pokusu pravice zlomit dosavadní trend československé politiky volbou za prezidenta republiky jiného politika, než doporučoval odstupující prezident Masaryk. Nakonec byl E. Beneš zvolen značnou většinou a zajímavé bylo, že pro něj hlasovali i komunističtí poslanci dosud zaujímající kritické stanovisko k republice a jejímu zrrízení. Kladla se otázka, zda demokratické tradice českého národa nesehrály svou úlohu i u československých komunistů, když jim to politika lidové fronty proti fašismu, probojovávaná proti Stalinovým názorům v Kominterně, jistým způsobem dovolovala.

Boj proti fašismu jak v mezinárodním měřítku, tak i uvnitř státu byl jasným programem vlády v Československu. Nejrůznější pokusy nacistické vlády z Berlína ovlivnit linii československé zahraniční politiky skončily neúspěšně, a tak přišly na pořad jiné formy. To, že první úder nebyl vojenský, ale diplomatický, souvisí s tím, že západní demokratické mocnosti Francie a Velká Británie se nechaly zatáhnout do politiky usmiřování útočníka a na konferenci v Mnichově společně s Itálií vydaly Československo na pospas Hitlerovi.

Československo, stojící v cestě nacistické expanzi na východ, muselo být odstraněno, když se ho nepodařilo rozbít zevnitř působením henleinovské páté kolony. Jeho demokratické zřízení se ukázalo dostatečně pevné, aby vnitřnímu nepříteli odolalo, a tak nezbylo nic jiného, než ho porazit na mezinárodní scéně. Československý lid se s tímto diktátem nikdy nesmíril a zajímavé bylo i to, že na obranu republiky zcela jednoznačně vystoupili i českoslovenští komunisté.

Nacistický vojenský úder rozdělil v roce 1939 Československo na Protektorát Čechy a Morava a Slovenský štát, ale kontakty mezi českým a slovenským národem se mu nepodařilo zcela přerušit. Jak zahraniční odboj, tak i český a z velké části i slovenský odboj počítaly s obnovou Československa a přes různé obtíže se o to společně zasazovaly. Podařilo se také, že komunisté se postupně zapojili do protinacistického odboje jak na mezinárodním, tak domácím poli. Vedení KSČ, sídlící v Moskvě, podpořilo E. Beneše jako hlavu zahraničního odboje a jak ve Slovenské národní radě, tak v České národní radě zasedli komunisté jako rovný s rovnými, což byla v evropském měřítku jakási výjimka. 
Protinacistický odboj nacházel podporu u velké většiny obyvatelstva, i když např́ílad podmínky pro partyzánský boj byly zvláště v českých zemích velmi malé. Nejdelší okupace v Evropě kladla na obyvatelstvo Cech a Moravy mimořádně velké nároky, ale ve své drtivé většině lidé vydrželi. Kritické pohledy na předválečný režim, které formulovaly odbojové organizace v zemi, byly ve své většině exilovou vládou akceptovány a revoluční plány na zlepšení demokracie po válce byly přijímány doma i v zahraničí.

Také evropské dimenzi mezinárodní politiky věnovala československá exilová vláda velkou pozornost. Zvlášé výrazně se to projevilo v úsilí vyloučit z ní pozůstatky mnichovanské politiky appeasementu, pro což našel prezident Beneš plné pochopení u francouzského generála de Gaulla, zastupujícího po kapitulaci Francii mezi spojenci v protihitlerovské koalici. Oba se shodovali v jisté obavě, aby tři velmoci, SSSR, USA a Velká Británie, stojící v jejím čele a mající širšsí než jen evropské zájmy, věnovaly Evropě dostatečnou pozornost. Poválečné zkušenosti ukázaly, že jejich obavy byly do jisté míry oprávněné.

Nejen Evropa, ale i demokracie stály v popředí pozornosti prezidenta Beneše. Jeho kniha „Demokracie dnes a zítra“, jejíž první verze vyšla již za války v Londýně, vyústoovala v názor, že by se demokracie po válce měla rozšsiririt z politické oblasti i do národního hospodářství, sociální sféry a kultury, což z velké části odpovídalo na požadavky domácího odboje. V jejím závěru docházel E. Beneš $\mathrm{k}$ názoru, že československá demokracie by se po válce měla stát socializující a humanitní. A to bylo opět v souladu s úvahami odbojového hnutí v mnoha evropských zemích, kde v poválečném období byly vypracovány nové ústavy, a to nejen v její východní části.

Osvobozené Československo našlo bez problémů své místo jak v evropské politice, tak v nově založené Organizaci spojených národů. Na Jaltě se o něm nejednalo, nebot už předem bylo jasné, že jeho jednota a demokratické zřízení bude v souladu s tam přijatým „Prohlášením o osvobozené Evropě“, které všem evropským státům, vítězným i poraženým, doporučovalo jak demokratické uspořádání vnitřní, tak zahraniční politiku založenou na těchto zásadách.

V zahraniční politice byla československá vláda připravena posloužit celé Evropě svou zeměpisnou polohou jako jakýsi most mezi Východem a Západem, což mohlo mít i širší než jen evropskou dimenzi. V tomto duchu uspořádalo Československo, kdysi označované za „konzervatoř Evropy“, hned v roce 1946 hudební festival „Pražské jaro“, který zůstal dodnes významným kulturním pojítkem Evropy a postupně i celého světa. Také filmový festival v Karlových Varech vytvořil podmínky pro spolupráci umělců z Evropy i dalších částí světa, a podařilo se ho, přes některé obtíže, udržet až do dneška. Velmi aktivně se Československo zapojilo do činnosti UNESCO, a to jak významnou pomocí při alfabetizaci národů z bývalých kolonií, tak rozsáhlými překlady významných literárních děl do češtiny, což upevňovalo kulturní sepětí Čechů a Slovákủ s kulturním děním v Evropě a ve světě.

Bipolární rozdělení Evropy koncem čtyřicátých let bylo v rozporu s chápáním jednoty kontinentu Čechy a Slováky, ale rozhodnutí bylo tehdy zcela jednoznačně v rukou supervelmocí. Československo se po zákazu účasti na Marshallově plánu ocitlo ve východním bloku, což minimalizovalo možnosti styků s druhou částí kontinentu. Týkalo se to nejen přerušení hospodářské spolupráce kvůli embargu na vzájemný obchod, ale i důsledku nesmyslné stalinské politiky zostřování třídního boje.

Teprve uvolnění mezinárodního napětí v polovině padesátých let, kdy politiku studené války začalo vytlačovat mírové soužití, mimo jiné po ženevské schůzce nejvyšších představitelů čtyř velmocí v červenci 1955, umožňovalo jisté styky mezi evropským Východem a Západem. Překonat odpor USA k pojmu mírové soužití se podařilo, až když generál de 
Gaulle po návratu do čela francouzské politiky dal uvolňování napětí francouzský výraz „détente“.

I když nemožnost cestovat omezovala poznávání cizích zemí, udržela si česká a slovenská společnost vysokou kulturní úroveň odpovídající evropskému standardu. Potvrzením toho se stala účast Československa na světové výstavě EXPO 1958 v Bruselu, kde československý pavilon byl označen za nejlepší. Vysokou kvalitu československé filmové tvorby, už několikrát mezinárodně oceněné, potvrdil „Polyekran“, promítání několika filmů současně, stejně jako „Laterna magica“, spojující filmové záběry s hranými částmi nebo s „Černým divadlem“. Stejně byly návštěvníky vysoce hodnoceny výborné kulinářské výrobky podávané v československých zařízeních.

Přes všechny obtíže zůstávalo Československo nejvyspělejší zemí v rámci Rady vzájemné hospodářské pomoci, což se mimo jiné promítalo i na zájmu obyvatel jiných členských států na turistické návštěvě Prahy i dalších měst. Rozhodnutí nejvyšších stranických a státních míst, že v Československu už byl vybudován socialismus, vedlo v roce 1960 k přijetí nové ústavy s článkem zakotvujícím vedoucí úlohu KSČ, a k pojmenování země Československou socialistickou republikou - ČSSR.

Nástup do šedesátých let přinesl jisté uvolnění ve vnitřní politice, což umožnilo kritičtější pohled na stav především národního hospodářství, které silně zaostávalo zvláště ve srovnání s rozvojem některých evropských zemí, především těch, jež se spojily v rámci Evropského hospodářského společenství. Hledání cest k ozdravění československé ekonomiky odbornými kruhy naráželo na odpor zkostnatělého vedení KSČ. Začaly se objevovat i některé problémy vztahů Čechů a Slováků kvůli asymetrickému uspořádání státu, když slovenské národní orgány nenacházely na české straně své partnery a podléhaly přímo celostátním institucím.

Bylo to v jistém rozporu s převládajícím trendem evropské politiky, kam se začínalo prosazovat uvolňování napětí a politika kontaktů a spolupráce. Československo se jen velmi těžce probojovávalo k účasti na tomto vývoji. Výjimkami bylo od roku 1962 úsilí v OSN o prosazení právní kodifikace mírového soužití a v Evropě memorandum k dvacátému výročí založení Evropské hospodářské komise v roce 1967. Dokument vycházel jak ze snah československých ekonomů o modernizaci národního hospodářství, tak z úvah o celoevropské hospodářské spolupráci. Československý dokument se zamýšlel nad budováním vodních cest, včetně průplavu Dunaj-Odra-Labe, nad dostavbou evropské dálniční a železniční sítě, modernizací ropovodů, plynovodů, propojení elektrovodných sítí atd., čímž potvrzoval př́islušnost Československa k Evropě.

Tento trend vyvrcholil „Pražským jarem 1968“, umožněným změnami ve vedení KSČ a politickou aktivizací obyvatelstva. Navrhované reformy v „Akčním programu“, připraveném novými silami v KSČ, byly veřejností plně přijímány, nebở představovaly skutečně hledání nových, demokratických a moderních forem v duchu „socialismu s lidskou tváŕíi“. Logické proto bylo, že se v československém parlamentu objevily úvahy o spolupráci nebo dokonce i o vstupu do Rady Evropy.

Podobné trendy nebyly jen specifikem Československa, ale v Evropě se šíriilo i hnutí „nové levice“, často ve spojení se studentským hnutím, hledající nové formy hospodářského, ale i politického uspořádání moderní společnosti. A tak není divu, že události v Československu přitahovaly zájem veřejnosti v celé řadě evropských zemí, ale i vládní kruhy v mnoha zemích sledovaly změny v ČSSR s nemalým zájmem, nebot’mohly mít i širší ohlas.

Vše však zastavil vpád sovětských a dalších vojsk do Československa, jenž ukončil „Pražské jaro“. Ne náhodou se tento krok silně odrazil v úpadku vlivu komunistických 
stran v západoevropských zemích, i když se snažily se od stalinského „reálného socialismu“ distancovat tzv. „eurokomunismem“.

Jediným výdobytkem „Pražského jara“ byla v Československu přestavba ústavy na federaci dvou národních republik. Tento model se však nepromítl do stranické struktury, kde přetrvala asymetrie, a podle sovětských směrnic „normalizovaná“ komunistická strana už nikdy důvěru veřejnosti nezískala.

Západ vždy považoval sovětský zásah v Československu v roce 1968 za vnitřní záležitost sovětského tábora, a proto neustoupil od zásadního souhlasu s myšlenkou celoevropské konference o bezpečnosti a spolupráci, kterou po de Gaullově návštěvě v SSSR navrhl v roce 1966 Politický poradní výbor Varšavské smlouvy v duchu generálova pojetí „Evropy od Atlantiku po Ural“.

Jen velmi těžko se Československo vzpamatovávalo z otřesu roku 1968, a pokud šlo o jeho př́íslušnost k Evropě, ta se projevovala jen postupně rozvojem družebních styků závodů a měst nejprve v rámci sovětského tábora, ale později i v jiných částech Evropy.

Orientace evropské politiky na celoevropskou konferenci se pozitivně promítlo do vývoje v Německu. Po vytvoření vlády sociálních demokratů a liberálů pod vedením W. Brandta v roce 1969 se nejen podařilo normalizovat vzájemné vztahy obou německých států, ale v duchu nové „východní politiky“ upravit i styky se socialistickými státy.

Tak se muselo i Československo, pod vedením nového ministra zahraničí B. Chňoupka, diplomaticky aktivovat a uzavř́t 11.12.1973 dohodu s SRN o navázání diplomatických styků, čemuž dosud mimo jiné bránil i spor o neplatnost mnichovského diktátu. Československá strana žádala neplatnost od samého počátku, což bylo pro německou stranu z mnoha důvodů neprijiatelné. Nakonec se podařilo dohodnout se na formulaci, že ČSSR a SRN „považují mnichovskou dohodu z 29. září 1938 vzhledem ke svým vzájemným vztahům podle této smlouvy za nulitní.“

Podobně se podařilo v téže době překonat složité problémy vzájemných vztahů s Rakouskem, nejprve smlouvou o společných hranicích a potom i definitivní smlouvou o vypořádání finančních a majetkových otázek. Konečně se mohly styky mezi oběma státy dostat na úroveň velvyslanectví, když vyslanectví už byla jistou kuriozitou v evropské a světové politice.

Pokrok v německé otázce otevřel cestu do Helsinek, kde se sešli zástupci všech evropských států (s výjimkou Albánie) a Kanady a USA na Konferenci o bezpečnosti a spolupráci v Evropě. Ukázalo se, že československý návrh na vytvoření stálého sekretariátu, který by dozíral na plnění přijatých usnesení a inicioval další kroky, byl pro většinu účastníků nepřijatelný. Avšak jednání o něm ve zvláštním „koši“ dospělo nakonec $\mathrm{k}$ dohodě v rámci „Závěrečného aktu“ z roku 1975 o následných schůzkách konference a tím o pokračování helsinského mírového procesu. Potvrdilo to oprávněnost československého návrhu, jenž dokázal schopnost Čechů a Slováků správně postihnout potřeby bipolárně rozděleného kontinentu.

Československá zahraniční politika se přece jen postupně zapojovala do evropské politiky, i když vždy jen tam, kde to bylo v souladu se sovětskou diplomacií. Politika mírového soužití přece jen otevírala některé možnosti $\mathrm{k}$ vyjádření i neoficiálních názorů na otázky mezinárodní politiky. V helsinském „Závěrečném aktu“ se všechny zúčastněné státy, tedy i Československo, zavázaly k respektování lidských práv. To už bylo v západní části kontinentu upraveno dokumenty Rady Evropy, především „Úmluvou o ochraně lidských práv a základních svobod“ z roku 1950, a v celosvětovém měřítku měly být Mezinárodní pakty 
o občanských, politických, hospodářských, sociálních a kulturních právech uznávány již od roku 1966, kdy byly schváleny v OSN.

A právě lidská práva dala československé opozici, označované většinou jako disent, podnět $\mathrm{k}$ tomu, aby se počátkem roku 1977 obrátila $\mathrm{v}$ „Chartě 77 “ na vládní místa s požadavkem plnit povinnosti, jež na sebe vzala př́stupem $\mathrm{k}$ různým dokumentům o lidských právech. Dokument, adresovaný parlamentu, odpovídal zákonům, a tak si vládní místa začala vymýšlet záminky k postižení těch, kdo chartu podepsali.

Různé tiskové a mediální kampaně proti „chartistům“ udělaly dokumentu tu nejlepší reklamu, a tak se stal známým v celé Evropě. Ćeskoslovenské hnutí za lidská práva se tak dostalo do popředí pozornosti evropské veřejnosti nejen díky této kampani, ale široké sympatie si zajistilo svou seriózností v př́stupu k těmto v Evropě tak ceněným zásadám, a proto se mu dostalo mimořádného uznání a mezinárodní podpory.

Československý chartismus se postupně stal významným podílníkem boje různých disidentských hnutí v zemích sovětského tábora. Právě z řad občanů přicházely podněty k respektování lidských práv, ale také kritika evropské bipolarity a požadavek obnovit jednotu kontinentu, a s tím spojená podpora helsinského mírového procesu. Československá veřejnost, jednoznačně podporující evropské úsilí o respektování lidských práv, se stále víc dostávala do rozporu s vládní politikou, různým způsobem blokující helsinský mírový proces právě proto, že jeho nedílnou součástí byl boj za lidská práva.

Následné schůzky Konference o bezpečnosti a spolupráci od roku 1977 ukazovaly, že „duch Helsinek“ nebyl dost silný, aby vytlačil záchvěvy studené války z evropské politiky. $\mathrm{Na}$ jedné straně se to projevilo $\mathrm{v}$ zahraniční politice USA, když nový prezident označil SSSR za „ř́ísi zla“, na druhé straně když vnitropolitická krize v Polsku vedla k vyhlášení mimořádného stavu, aby se odvrátilo nebezpečí intervence vojsk Sovětského svazu.

V zahraničně politické orientaci ČSSR se proti jistému pragmatismu Ministerstva zahraničních věcí postupně stále více prosazoval vliv dogmaticky myslícího mezinárodního oddělení ÚV KSČ a tomu více vyhovovalo zvyšování mezinárodního napětí. Takže diplomacie se vyžívala počátkem osmdesátých let $\mathrm{v}$ sjednávání smluv o přátelství a spolupráci s Afghánistánem, Angolou, Etiopií, Jemenem, Korejskou lidově demokratickou republikou, Laosem, Libyí, Sýrií a Vietnamem. V Evropě byla v roce 1977 sjednána pouze spojenecká smlouva s Německou demokratickou republikou.

Za diplomatické úspěchy lze však označit ukončení řadu let se táhnoucích jednání o urovnání vztahů s Vatikánem, jež vedla v roce 1977 k uvedení církevních hranic do souladu se státními hranicemi ČSSR, a k jmenování některých nových biskupů na Slovensku. Ještě důležitějš̌i byla dohoda s USA o vypořádání určitých otevřených nároků a finančních otázek z 29. 1. 1982.

Oběma diplomatickým dokumentům se dostalo minimální publicity a tak o dobré jméno Československa se daleko více zasluhovali opoziční představitelé Charty 77, zveřejňující stanoviska veřejnosti jak k vnitropolitickým, tak mezinárodním problémům. K nejvýznamnějším patřív evropské politice „Pražská výzva Charty 77“ z 11.3. 1985, adresovaná mírovému kongresu v Amsterdamu, vyslovující se proti bipolárnímu rozdělení Evropy. Vládní místa naproti tomu účastí na prodloužení platnosti Varšavské smlouvy 26. 4. 1985 pomáhala toto bipolární rozdělení zachovat.

Evropská politika dostala zcela nové impulzy po nástupu M. S. Gorbačova do funkce generálního tajemníka ÚV KSSS v březnu 1985, který svou koncepcí „,nového politického myšlení“ a návrhem na „společný evropský dům“ navazoval na kroky k mezinárodnímu 
uvolnění, jež v sovětské zahraniční politice učinil po vystřídání L. I. Brežněva na čele KSSS J. V. Andropov. Při své návštěvě Prahy sice M. Gorbačov zklamal Čechy i Slováky, nebot’se nevyslovil kriticky ke vstupu sovětských vojsk do Československa v roce 1968, ale svými slovy o snaze právě z Prahy, středu Evropy, odmítnout cestu jaderného zbrojení v Evropě, ale soustředit se „na mírový vývoj mnohostranné a zároveň celistvé evropské kultury“, vytýčil novou linii sovětské zahraniční politiky.

Postupně se prosazující uvolnění mezinárodního napětí umožnilo rozvoj styků a jistou spolupráci disidentů v zemích socialistického tábora, i když jejich aktivita se dosti různila. Poláci, opírající se o sílu dělnické „Solidarity“, usilovali o jednání s vládou u kulatých stolů, Mad’ařise soustředili na otázky ekologické a v NDR využívali opozičníci podpory evangelických far a žádali, podobně jako českoslovenští chartisté, dodržování demokratických zásad ústavy.

Československo se stále více dostávalo do obtíží, když významní evropští státníci na návštěvě v Praze vyžadovali zařadit do plánu pobytu i setkání s představiteli disidentů a ve svých oficiálních projevech se nezrríkali kritických poznámek na vnitřní situaci v Československu. To nakonec vyvrcholilo koncem roku 1988 tím, že F. Mitterrand, jenž jako první francouzský prezident v dějinách navštívil Československo, pozval skupinu chartistů na snídani na francouzské velvyslanectví.

Na třetí následné schůzce KBSE ve Vídni se podařilo díky pružnosti nové sovětské diplomacie najít cestu ke konferenci o snížení stavu klasických zbraní v Evropě a v rámci „Lidské dimenze“ podniknout významné akce na obranu lidských práv v Evropě. Vládní místa splnila povinnost vydat „Závěrečný dokument“ této schůzky, ale o její propagaci se více zasloužila opozice, jež například ve spolupráci s „Mezinárodním helsinským výborem“ ustavila „Československý helsinský výbor“ a „Sdružení za evropský dům“, hlásící se ke Gorbačovově myšlence. Proti sílícímu vlivu obránců lidských práv, dokumentovaným mimo jiné úspěchem legální oslavy 40 . výročí přijetí Všeobecné deklarace lidských práv v OSN 10. 12. 1988 na Žižkově s hlavním řečníkem V. Havlem, vytvořila vládní místa „Výbor československé veřejnosti pro lidská práva“, kam se mohli zapojit i někteří opozičníci, ale vládní odpor proti politice obrany lidských práv se tím nijak nezměnil.

Rok 1989 přinesl do evropské politiky převratné změny. V Mad’arskudošlo k výměně stranického vedení a k uvolnění hranic s Rakouskem, v Polsku se podařilo ustavit vládu $\mathrm{v}$ čele s nekomunistou a v NDR docházelo k masovým demonstracím o nedělích po skončení bohoslužeb v kostelech. Mnoho občanů NDR využilo možnosti přes Mad'arskoa Rakousko se dostat do SRN a jiní se uchýlili na území západoněmeckých velvyslanectví v Praze a ve Varšavě. Vyvrcholením byl propad oslav 40. výročí vzniku NDR v ř́ínu 1989, $\mathrm{k}$ němuž přispěla i kritická slova $\mathrm{M}$. Gorbačova $v$ Berlíně, po nichž brzy následoval rozklad stranického a státního vedení NDR, jež vedl k pádu „Berlínské zdi““.

Československo nemohlo zůstat stranou, ovšem vývoj šel v něm zvláštní cestou. Povolená studentská manifestace k 50. výročí zákazu českých vysokých škol nacisty 17. 11.1989 byla policií nakonec rozehnána a zpráva o smrti jednoho ze studentů vyvolala takový ohlas veřejnosti, že stranické vedení kapitulovalo a ponechalo vývoj situace jejímu osudu.

Rychlé ustavení „Občanského fóra“ jako představitele opozice a ochota některých významných představitelů vedení KSČ $\mathrm{k}$ př́ímému jednání vedly $\mathrm{k}$ vytvoření „Vlády národního porozumění“ a krátce nato i k volbě Václava Havla prezidentem republiky. Důstojný a demokratický průběh těchto převratných změn v Československu vedl k jejich označení světovými médii za „sametovou revoluci“. Československo se vydalo na cestu obnovy de- 
mokracie a plného zapojení se do Evropy, což dokázalo jak vládní prohlášení a koncepce její zahraniční politiky, tak projevy prezidenta a jeho navazující první cesty do zahraničí.

Ministrem zahraničí nové vlády se stal jeden z disidentů, J. Dienstbier, a pod jeho vedením si vláda nejprve vynutila odchod sovětských okupačních vojsk, jako předpoklad svobodné zahraniční politiky. Její evropskou orientaci doložilo memorandum z 6. 4. 1990 o Evropské bezpečnostní komisi, jež měla otevřít cestu k novým vztahům v Evropě míru a bezpečnosti. Zároveň bylo zahájeno jednání s Evropskými společenstvími o možnosti přidružení, k čemuž došlo koncem roku 1990 „Evropskými smlouvami“ s Československem, Mad'arskem a Polskem.

Součástí hledání bylo i pozvání prezidenta Havla k schůzce nejvyšších představitelů těchto tř́ sousedních zemí do Bratislavy, jež zahájila jejich spolupráci podepřenou „Deklarací o spolupráci na cestě evropské integrace“, schválenou 15. 2. 1991 v mad’arskémVisegrádu. Sem logicky patří i zapojení Československa do „Adriatické iniciativy“ čtyř, založené v roce 1989 Itálií, Jugoslávií, Mad’arskema Rakouskem, které z ní na jaře 1990 udělalo „Pentagonálu“ a později se stala Středoevropskou iniciativou (SEI).

Aktivní účast československé diplomacie na přípravě setkání účastníků KBSE na nejvyšší úrovni, která přijala v listopadu „Pařížskou chartu pro novou Evropu“, přispěla k tomu, že pro nově utvořenou Radu KBSE byla vybrána Praha za sídlo sekretariátu. To jenom potvrzovalo, stejně jako počátkem roku 1991 přijetí Československa do Rady Evropy, jeho př́slušnost do Evropy. Všechny tyto kroky byly v souladu s přáním obyvatelstva, jež ve své drtivé většině přijímalo zapojení do sjednocující se Evropy za samozřejmost.

Vývoj však nebyl tak jednoduchý. Československo se v roce 1992 rozdělilo na Českou republiku a Slovenskou republiku a česká vláda zdaleka nesledovala tak jednoznačně proevropskou politiku, jak se dřive předpokládalo. Zahraniční politice věnovala tehdejší vláda jen nezbytné minimum pozornosti a před zapojením se do evropského integračního procesu dávali v ní převládající euroskeptici přednost orientaci na USA. Proto dostalo přednost úsilí o vstup do NATO a žádost o vstup do Evropské unie podalo Česko z vybraných zemí jako poslední.

Teprve menšinová vláda sociální demokracie, jež věnovala velkou pozornost vypracování koncepce české zahraniční politiky, byla orientována jednoznačně evropsky a po zapojení České republiky do NATO v roce 1999 se cílevědomě zasadila o její přijetí do Evropské unie, k němuž došlo, po schválení tohoto kroku lidovým hlasováním, 1. 5. 2004.

Češi vždy žili ve středu Evropy, a proto si vždy uvědomovali svou příslušnost $\mathrm{k}$ tomuto kontinentu. České národní hnutí od svého obrození vždy věnovalo Evropě velkou pozornost, aby s co největší znalostí věcí formulovalo svůj přístup k mezinárodní problémům. Díky tomu průměrný Čech ví o Evropě a jejích dějinách většinou více než př́islušníci jiných evropských národů, u nichž zahraniční politika bývala často ovlivňována silným nacionalismem. Tyto vlastnosti pomáhaly českým emigrantům uplatnit se v jiných evropských zemích a dá se proto předpokládat, že Čechům nepřinese vstup do sjednocující se Evropy žádné zvláštní problémy, nebơ vždy se do velké míry Evropany cítili. 